\title{
THE IMPACT OF HEAT STRESS AND ENZYME SUPPLEMENTATION ON THE BIOAVAILABLE ENERGY OF SOME FEEDSTUFFS USED IN POULTRY DIETS
}

\author{
M.N. Makled ${ }^{1}$, T.M. El-Sheikh ${ }^{1}$, M. A. Metwally ${ }^{1}$ and S.H. El Nagar ${ }^{2}$ \\ 1- Department of Animal and Poultry Production, Faculty of Agriculture, of \\ Assiut, 2- Department of Animal and Poultry Production, Faculty of Agriculture, \\ University of Sohag
}

\section{SUMMARY}

Four feed ingredients; mung beans, sorghum, rice bran and wheat bran were used in four similar experiments. Each experiment was carried out to evaluate the proximate chemical analyses and bioavailability of energy (apparent metabolizable energy, AME, apparent metabolizable energy corrected to zero nitrogen balance, $A M E_{n}$; true metabolizable energy, TME and true metabolizable energy corrected to zero nitrogen balance, $T M E_{n}$ ) of each of the feed ingredients under study either under thermoneutral $\left(24^{\circ} \mathrm{C}\right)$ or cyclic heat stress $\left(8 \mathrm{hrs}\right.$ at $38^{\circ} \mathrm{C}$ and $16 \mathrm{hrs}$ at $24^{\circ} \mathrm{C}$ ) without or with enzyme supplementation (either optizyme at level of $300 \mathrm{mg} / \mathrm{kg}$ or phytase at level of 1500 FTU/kg feed). Forty sixteen-month old mature Dandarawi roosters divided into eight groups of five birds each were used in these experiments. Force feeding was applied for determining apparent and true metabolizable energy. The results showed that:

1. Mung beans have a high percent of protein (24.83\%) which makes it a suitable source of protein in poultry diets; sorghum has a high percent of nitrogen free extract (72.80\%) which make it a suitable source of energy; rice bran has a high percent of ether extract (11.01\%) and wheat bran has a high percent of crude fiber $(6.58 \%)$.

2. Heat stress had a tendency to decrease $A M E, A M E_{n}, T M E$ and $T M E_{n}$ for the studied material except sorghum, however, the decrease was not significant.

3. Enzyme supplementation tended to increase the values of the different forms of metabolizable energy values especially in case of optizyme supplementation to rice bran and phytase to wheat bran. However, the differences didn't reach a significant level $(P>0.05)$.

4. The interaction between heat stress and enzyme supplementation seemed to have a slight tendency to improve metabolizable energy values but without any significance at $P<0.05$ for any of the four feedstuffs under study. This slight improvement was more obvious at optizyme supplementation to rice bran and at phytase supplementation to wheat bran both under heat stress.

It may be concluded that heat stress at $38{ }^{\circ} \mathrm{C}$ tended to have a negative effect on the energetic values of the feedstuffs under study. The impact of enzyme supplementation on energy values tended to be positive in general. However, it may

Issued by The Egyptian Society of Animal Production 
be more effective at more severe heat stress $\left(>35^{\circ} \mathrm{C}\right)$ or at higher levels of enzymes supplementation than those used in this study (1500 FTU phytase or $0.3 \mathrm{~g}$ optizyme/kg feed).

Keywords: Metabolizable energy, Dandarawi chickens, heat stress, mung beans

\section{INTRODUCTION}

Mung beans (phaseolus aureus) is a short summer crop cultivated in some Asian countries (Khalaf Allah, 1995) and warmer parts of Canada and United States (Rosario and Noel, 1980). Mung beans include many species and varieties. In Egypt it named Indian bean (Ashour et al., 1991). Mung bean in Egypt is cultivated in some areas in Nubaria, Giza, Ismailia and Sinai. It contains $20-30 \%$ crude protein (ElSayed, 1999). Mung beans have a favorable amounts of essential amino acids, minerals, vitamins and energy (Khalil, 1996 and El-Alfy, 1998), also, its content of anti-nutritional factors are very low (Chitra et al., 1995). The low availability of phytate-phosphorus (NRC, 1994) in plant seeds could be raised by hydrolysis with microbial phytase (Simons, et al., 1990). For these reasons, producers may use mung beans as a feed ingredient for animal and poultry (Ashour et al., 1991 and El-Alfy, 1998).

Sorghum grains could replace yellow corn in chick diets and has energy equivalent to 96-98\% of yellow corn (Sullivan, 1987 and Nyachoti et al., 1997). Although the nutritive value of the Egyptian sorghum grains is not very high (Fayek and Mady, 1989), there is an increase in usage of sorghum in poultry diets during the short supply of corn (Fayek et al., 1989). The tannins and polyphenols in sorghum act as anti-nutritional factors with negative effects varying widely according to their composition and the extent of polymerisation (Gualtieri and Rapaccini, 1990). Improvement in the nutritional value of Egyptian sorghum was achieved by addition of phosphates (Ibrahim et al., 1988) or methionine (Makled and Afifi, 2000).

Oil-extracted rice bran contains over $700 \mathrm{~g} / \mathrm{kg}$ non-starch polysaccharide (NSPs) of which oraban and xylan are predominant (Annison et al., 1995). These may have an adverse effect on the digestion of some dietary components. However, Farrell and Martin (1998) concluded that non-starch polysaccharide fractions were not significant factors in altering the nutritive value of rice bran and the enzymes supplementation were therefore unlikely benefit in diets of chickens and ducks.

The negative effects of heat stress on growth rate and production are due to reduced feed intake of broilers (Hurwitz et al., 1980) and laying hens (Savory, 1986). Also, heat stress reduce the availability of important nutrients (Koelkebeck et al., 1998) and decrease the digestibility of some amino acids (Wallis and Balnave, 1984; Zuprizal et al., 1993 and Makled et al., 2000).

Makled et al. (2000) found that the acute cyclic heat stress $\left(24-35^{\circ} \mathrm{C}\right)$ reduced the $\mathrm{TME}_{\mathrm{n}}$ of corn, sorghum, soybean meal and wheat bran.

Cell wall components and anti-nutritional factors are considered as problems in several feedstuffs. Microbial enzymes with possible impact on these factors have been identified and tested. The possible effects of enzymes on digestion have been outlined by Bedford (1996). It was indicated that the enzymes in feed might improve ingredient digestibility disruption of plant cell walls; destruction of anti-nutritional 
factors; supplementation of endogenous and manipulation of gut micro-flora populations (Bedford 1996).

Farrell and Martin (1998) and Ravindran et al. (1999) reported that phytase addition to chick or duck diets containing corn, cotton seed meal or soybean meal, wheat or wheat bran and rice bran improved metabolizable energy value. This improvement may be due to liberation of calcium ions needed for activation of $\alpha$ amylase which involved in starch digestion and/or the improvements in protein/amino acid utilization (Ravindran, et al. 1999). Wu et al. (2004) found that phytase addition improved AME values of wheat-based diets but had little effect on AME of maize-based diets.

Several studies found that enzymes are beneficial to improve the utilization of minerals, growth performance, egg production and blood parameters (Attia et al., 2000; Boling et al. 2000 and Keshavarz, 2000). Moreover, phytase enzyme improves phosphorus utilization by breaking down phytate that binds phosphorus in plant materials (Schoner et al., 1991 and Jeroch and Peter, 1994). Other studies reported that phytase can improve the performance of broiler chickens (Simons et al., 1990; Broz et al., 1994; Qian et al., 1996 and Van der Klis et al., 1997) and energy utilization (Ravindran and Bryden, 1997 and Namkung and Leeson, 1999).

The aim of the present study was to determine the impact of enzymes supplementation in a single form (Phytase) or a mixture form (Optizyme) under thermoneutral or heat stress conditions on the different values of bioavailable energy of mung beans, sorghum, rice bran and wheat bran.

\section{MATERIALS AND METHODS}

\section{Birds and management}

This study was carried out at the Poultry Research Farm, Faculty of Agriculture, Assiut University, Assiut, Egypt. Four similar experiments were conducted with four feed ingredients: mung beans, sorghum, rice bran and wheat bran. Each experiment was carried out to evaluate the proximate chemical analysis and bioavailable energy values (apparent metabolizable energy,AME; apprent metabolizable enegy corrected to zero nitrogen balance, $\mathrm{AME}_{\mathrm{n}}$; true metabolizable energy, TME and true metabolizable energy corrected to zero nitrogen balance, $\mathrm{TME}_{\mathrm{n}}$ ) of each one of the feed ingredients under study either under thermoneutral or cyclic heat stress; with or without enzymes supplementation either in a single form (phytase) or in a blend form (optizyme).

In each experiment 40 Dandarawi cockerls 16-month old, were randomly assigned into eight groups of five birds each. Group 1 (general control) in which birds were kept under thermoneutral conditions $\left(24^{\circ} \mathrm{C}\right)$ and received the feed ingredient understudy without enzyme supplementation. Group 2 (control for group 5) was kept under thermoneutral conditions $\left(24^{\circ} \mathrm{C}\right)$ and received the feed ingredients understudy beside optizyme supplement at $300 \mathrm{mg} / \mathrm{kg}$ feed. Group 3 (control for group 6) was kept under thermoneutral conditions $\left(24^{\circ} \mathrm{C}\right)$ and received the feed ingredient understudy beside phytase supplement at $1500 \mathrm{FTU} / \mathrm{kg}$ feed. Group 4 which kept under cyclic heat stress $\left(8 \mathrm{hrs}\right.$ at $38^{\circ} \mathrm{C}$ and $16 \mathrm{hrs}$ at $\left.24^{\circ} \mathrm{C}\right)$ and received the feed ingredients understudy without any enzyme supplementation. Group 5 (As group 4, however, birds received the feed ingredient under study beside optizyme supplement at $300 \mathrm{mg} / \mathrm{kg}$ feed. Group 6 (As group 4, however, birds received the 
feed ingredients under study beside phytase supplement at $1500 \mathrm{FTU} / \mathrm{kg}$ feed. Group 7 was kept fasted for the whole experimental period under thermoneutral conditions (as fasted control birds). Group 8 was kept fasted for the whole experimental period under cyclic heat stress (as fasted heat stressed control birds).

The experiments were conducted using force feeding methodology of Sibbald (1976). The birds were kept individually in metabolic cages with plastic trays under cages to collect the excreta. Each experiment lasted for 18 days according to the following timetable: Day 1, roosters were moved to the experimental chamber in the afternoon. Day 2 to day 14, adjustment period (feed and water ad lib.). Days 15 and 16 fasting period (feed off for $30 \mathrm{hrs}$ ). Day 16 (funnel force feeding), at the end of fasting period, birds were fed using funnel and forced with $30 \mathrm{~g}$ mung beans or $30 \mathrm{~g}$ sorghum or $20 \mathrm{~g}$ of rice bran or $20 \mathrm{~g}$ wheat bran. Day 16 to 18 (excreta collection) for $48 \mathrm{hrs}$, start just after funnel feeding.

The above mentioned steps were done for groups 1, 2, 3 and 7 under thermoneutral conditions and for groups 4, 5, 6 and 8 under cyclic heat stress.

The birds were kept for recovery period (14 days) between each two following experiments.

\section{Enzyme preparation}

The enzyme preparations used in this study were 1. Micoribial phytase which produced from Aspergillus neiger in a powder produced by Gistbrocades, The Netherlands and BASF, Germany, at two levels (0 and 1500 FTU/kg). FTU is the quantity of enzyme required to produce 1 micromol of inorganic phosphorus $/ \mathrm{min}$ from $5.1 \mathrm{mmol} / \mathrm{L}$ of $\mathrm{Na}$ phytate at a $\mathrm{pH}$ of 5.5 and a water-bath temperature of $37^{\circ} \mathrm{C}$ (Boling et al. 2000). The $1500 \mathrm{FTU}$ used in the present study equal to $0.3 \mathrm{~g}$ phytase $/ \mathrm{kg}$ tested material. 2. Optizyme produced by Optivite International LTD, Main street, Laneham, Retford, Nottinghamshire, DN 22 OVA, England, at two levels ( 0 and $0.3 \mathrm{~g} / \mathrm{kg}$ tested material). Optizyme is a blend of enzymes which contains proteases, hemicellulases, cellulases, xylanase, $\beta$-glucanase and amyloglucosidases.

\section{Preparation of excreta samples for analysis}

Excreta collected from each bird at the end of each experiment was dried in electric oven at $70{ }^{\circ} \mathrm{C}$ for $24 \mathrm{hrs}$. Samples of dried excreta were weighed and ground to pass through a 20 -mesh sieve, left for $24 \mathrm{hrs}$ in Lab. for moisture equilibrium and stored in glass containers till analysis.

\section{Proximate chemical analysis and gross energy determination}

Proximate chemical analysis of the tested feed ingredients were determined using methods of AOAC (1984). Nitrogen content of excreta was also determined by the same previous mentioned methods.

Feed and excreta samples were assayed for gross energy content using Ballistic Bomb Calorimeter (H250 Gallenkamp).

5. Calculation of bioavailavle energy ( $A M E, A M E_{n}, T M E$ and $T M E_{n}$ )

Metabolizable energy values were calculated according to Sibbald (1986) as follows:

$\mathrm{AME} / \mathrm{g}$ of feed $=\left[\left(\mathrm{F}_{\mathrm{i}} \times \mathrm{GE}_{\mathrm{f}}\right)-\left(\mathrm{E}_{\mathrm{f}} \times \mathrm{GE}_{\mathrm{e}}\right)\right] / \mathrm{F}_{\mathrm{i}}$ 


$$
\begin{gathered}
\mathrm{AME}_{\mathbf{n}}=\left[\left(\mathrm{F}_{\mathrm{i}} \times \mathrm{GE}_{\mathrm{f}}\right)-\left\{\left(\mathrm{E}_{\mathrm{f}} \times \mathrm{GE}_{\mathrm{ef}}\right) \pm \mathrm{K}\left(\mathrm{N}_{\mathrm{if}}-\mathrm{NO}_{\mathrm{ef}}\right)\right\} / \mathrm{F}_{\mathrm{I}}\right. \\
\mathrm{TME}=\left[\left(\mathrm{F}_{\mathrm{i}} \times \mathrm{GE}_{\mathrm{f}}\right)-\left\{\left(\mathrm{E}_{\mathrm{f}} \times \mathrm{GE}_{\mathrm{ef}}\right)-\left(\mathrm{E}_{\mathrm{c}}-\mathrm{NO}_{\mathrm{ec}}\right)\right\}\right] / \mathrm{F}_{\mathrm{I}} \\
\mathrm{TME}_{\mathbf{n}}=\left[\left(\mathrm{F}_{\mathrm{i}} \times \mathrm{GE}_{\mathrm{f}}\right)-\left\{\left(\mathrm{E}_{\mathrm{f}} \times \mathrm{GE}_{\mathrm{ef}}\right)+\mathrm{K}\left(\mathrm{N}_{\mathrm{if}}-\mathrm{NO}_{\mathrm{ef}}\right)\right\}+\right. \\
\left.\quad\left\{\left(\mathrm{E}_{\mathrm{c}} \times \mathrm{GE}_{\mathrm{ec}}\right) \pm \mathrm{K}\left(\mathrm{NI}_{\mathrm{c}}-\mathrm{NO}_{\mathrm{ec}}\right)\right\}\right] / \mathrm{F}_{\mathrm{I}} \\
\text { Where } \mathrm{F}_{\mathrm{i}}=\text { feed intake }(\mathrm{g}) .
\end{gathered}
$$

$\mathrm{E}_{\mathrm{f}}=$ excreta output $(\mathrm{g})$ of fed birds.

$\mathrm{GE}_{\mathrm{f}}=$ gross energy $(\mathrm{g})$ of feed.

$\mathrm{GE}_{\mathrm{e}}=$ gross energy $(\mathrm{g})$ of excreta.

$\mathrm{N}_{\mathrm{if}}=\mathrm{F}_{\mathrm{i}} \times \mathrm{N}_{\mathrm{f}}$

$\mathrm{NO}_{\mathrm{ef}}$ is the amount of nitrogen output per bird fed the tested materials.

$\mathrm{NO}_{\mathrm{ef}}=\mathrm{E}_{\mathrm{f}} \times \mathrm{N}_{\mathrm{ef}}$.

$\mathrm{N}_{\mathrm{f}}=$ the amount of nitrogen of feed $(\mathrm{g})$.

$\mathrm{N}_{\text {ef }}$ is the amount of nitrogen $(\mathrm{g})$ of the excreta of fed birds.

$\mathrm{K}=$ constant which estimates the gross energy content of the excretory

Products resulting from the catabolism of a unit weight of tissue

Nitrogen. The energy content of uric acid $(8.73 \mathrm{kcal} / \mathrm{g})$.

$\mathrm{E}_{\mathrm{c}}=$ the excreta output (g) of fasted control birds.

$\mathrm{GE}_{\mathrm{ec}}=$ gross energy of excreta of fasted control birds.

$\mathrm{NI}_{\mathrm{c}}=$ nitrogen input of excreta fasted control birds $(\mathrm{g}) . \mathrm{NI}_{\mathrm{c}}=$ zero.

$\mathrm{NO}_{\mathrm{ec}}=$ excreta nitrogen output of fasted control birds $=\mathrm{E}_{\mathrm{c}} \times \mathrm{N}_{\mathrm{ec}}$.

\section{Statistical analysis}

Statistical analysis for bioavailable energy values were conducted using the General Linear Model (GLM) procedure of SAS (1987). The following model was used:

$$
Y_{i j k}=\mu+T_{i}+P_{j}+(T P)_{i j}+e_{i j k} .
$$

Where $\mathrm{Y}=$ the observation.

$\mu=$ General mean.

$\mathrm{T}_{\mathrm{i}}=$ effect due to temperature.

$\mathrm{P}_{\mathrm{j}}=$ effect due to enzymes preparation.

$\mathrm{TP}_{\mathrm{ij}}=$ effect of interaction between enzymes and temperature.

$\mathrm{e}_{\mathrm{ijk}}=$ the error related to individual observation.

The significant differences between treatment means were tested by Duncan's multiple range test (Duncan 1955). The significant differences between interactions were tested by least square differences.

\section{RESULTS AND DISCUSSION}

\section{Chemical composition of the feedstuffs understudy}

The results of chemical composition of the feedstuffs understudy are represented in Tables 1 and 2. The results showed that mung bean has a high value of protein ( $24.83 \%$ on as fed basis) which makes it considered as a source of protein in poultry diets. Creswell (1981) found that mung bean contains $23.9 \%$ crude protein which supports a good growth of broiler chickens at a level up to $40 \%$ of the diet. Moreover, raw mung bean doesn't appear to contain anti-nutritional factors such as those found in soybeans (Kienholz et al., 1962).

The chemical composition showed that sorghum has high value of nitrogen free extract $(72.80 \%$ on as fed basis). Therefore, it may be used as a source of energy; however, it contains ant-nutritional factors such as tannins, non starch polysaccarides 
(NSP's), polyphenols and phytates (Luis and Sullivan, 1982 and Gualtier and Rapaccini, 1990), so using enzymes supplementation may be helpful in improving its nutritive value. The same suggestion may be applicable to rice bran which has high ether extract and crude protein contents and NSP's (Annison et al., 1995).

Table 1. Chemical composition of mung beans, sorghum, rice bran, and wheat bran (as fed basis)

\begin{tabular}{lcccc}
\hline Composition (\%) & Mung beans & Sorghum & Rice bran & Wheat bran \\
\hline Moisture & 9.54 & 10.06 & 13.86 & 10.04 \\
Dry matter & 90.46 & 89.94 & 86.14 & 89.96 \\
Organic matter & 86.82 & 88.43 & 74.86 & 85.40 \\
Crude protein & 24.83 & 11.72 & 11.72 & 16.49 \\
Ether extract & 0.54 & 2.42 & 11.01 & 2.42 \\
Crude fiber & 3.63 & 1.49 & 6.30 & 6.58 \\
Ash & 3.64 & 1.51 & 11.28 & 4.56 \\
Nitrogen free extract & 57.82 & 72.80 & 45.83 & 59.91 \\
\hline
\end{tabular}

Table 2. Gross energy (Kcal/kg) and amino acid (\%) contents in mung bean, sorghum, rice bran and wheat bran

\begin{tabular}{lcccc}
\hline Item & $\begin{array}{l}\text { Mung } \\
\text { beans }\end{array}$ & Sorghum & Rice bran & Wheat bran \\
\hline $\begin{array}{l}\text { Gross energy (Kcal/kg) } \\
\text { Amino acids (\%) }\end{array}$ & 3909 & 4611 & 3703 & 4138 \\
Threonine & & & & \\
Serine & 0.77 & 0.41 & 0.22 & 0.54 \\
Glutamic acid & 1.15 & 0.48 & 0.25 & 0.63 \\
Proline & 4.30 & 1.40 & 0.88 & 2.53 \\
Glycine & 0.58 & 0.78 & 0.69 & 0.98 \\
Cystine & 1.20 & 0.81 & 0.33 & 0.80 \\
Valine & 0.03 & 0.30 & 0.02 & 0.06 \\
Methionine & 0.75 & 0.40 & 0.30 & 0.47 \\
Isoleucine & 0.20 & 0.13 & 0.16 & 0.10 \\
Leucine & 1.05 & 0.64 & 0.29 & 0.64 \\
Tyrosine & 1.74 & 1.17 & 0.70 & 0.91 \\
Phenylalanine & 0.70 & 0.39 & 0.21 & 0.40 \\
Histidine & 1.01 & 0.43 & 0.31 & 0.40 \\
Lysine & 0.61 & 0.30 & 0.24 & 0.26 \\
Arginine & 2.04 & 0.72 & 0.19 & 0.67 \\
\hline
\end{tabular}

The chemical composition of rough wheat bran showed that it has $16.49 \%$ crude protein. It is lower than that reported by NRC (1994) and Metwally (1990). Also, it has high crude fiber content $(6.58 \%$ on as fed basis) which may affect the protein digestion.

Choct (2002) reported that mung bean, rice bran and sorghum have NSP in different percentages. The adverse effects of soluble NSP on the digestion and absorption of nutrients in monogastric animals and poultry are due to their ability to increase the viscosity of the digesta, to modify the physiology of the gastrointestinal tract and to change the ecosystem of the gut. The net effects may include altered of 
nutrient digestion and absorption pattern, i.e. enzymatic digestion $v s$ microbial fermentation.

The results in Table 2 indicate that sorghum is the highest in gross energy value, while rice bran is the lowest. Moreover, mung bean is the highest in amino acid contents, while rice bran is the lowest.

Nevertheless, mung bean showed high values of glutamic, leucine, arginine and lysine. However, wheat bran showed the lowest value in methionine but arginine and lysine in rice bran.

\section{Bioavailable energy values}

The results in Tables from 3 to 6 reveal the effect of heat stress, enzymes supplementation and their interactions on the different forms of metabolizable energy:

Table 3. The effect of heat stress and enzymes supplementation on apparent and true metabolizable energy values of mung beans

\begin{tabular}{lcccc}
\hline Treatment & AME & AME $_{\mathbf{n}}$ & TME & TME $_{\mathbf{n}}$ \\
\hline Temperature & & & & \\
Thermoneutral (N) & 2716 & 2716 & 3221 & 3221 \\
Heat stress (H) & 2627 & 2627 & 3130 & 3130 \\
Enzymes: & & & & \\
Without (W) & 2643 & 2643 & 3151 & 3151 \\
With optizyme (OP) & 2692 & 2692 & 3194 & 3194 \\
With phytase (PH) & 2680 & 2680 & 3181 & 3181 \\
Interactions: & & & & \\
N x W & 2707 & 2707 & 2707 & 3219 \\
N x OP & 2721 & 2722 & 2722 & 3223 \\
N x H & 2721 & 2721 & 2721 & 3221 \\
H x W & 2580 & 2580 & 2580 & 3083 \\
H x OP & 2662 & 2662 & 2662 & 3165 \\
H x PH & 2639 & 2639 & 2639 & 3141 \\
& & Probability & & \\
Temperature (T) & NS & NS & NS & NS \\
Enzymes (E) & NS & NS & NS & NS \\
T x E & NS & NS & NS & NS \\
\hline "Probability at 0.05 & & & & \\
\hline
\end{tabular}

*Probability at 0.05 .

\subsection{Effect of heat stress on energy bioavailability}

There was general trend that all the values of different forms of metabolizable energy $\left(\mathrm{AME}, \mathrm{AME}_{\mathbf{n}}, \mathrm{TME}\right.$ and $\mathrm{TME}_{\mathbf{n}}$ ) for all feed ingredients under study except sorghum decreased under heat stress. However, the differences were not significant. The obtained results are in partial agreement with those obtained by El-Husseiny and Greger (1980); Keshavaraz and Fuller (1980); Wallis and Blanve (1984); Geraert et al. (1992) and Bonnet et al. (1997). They all reported that heat stress decreased the values of metabolizable energy in the different feedstuffs under study. The reduction of energy values of mung bean, rice bran and wheat bran are also in agreement with the results reported by Makled et al. (2000). The reason of reducing metabolizable values under heat stress may be due to the increase of fat percentage in excreta that caused high quantities of energy loss. From the obtained results, the $\mathrm{AME}_{\mathbf{n}}$ and 
$\mathrm{TME}_{\mathbf{n}}$ values had slightly increased than AME and TME because the value of nitrogen in excreta was very low.

Table 4. The effect of heat stress and enzymes supplementation on apparent and true metabolizable energy values of sorghum

\begin{tabular}{lcccc}
\hline Treatment & AME & AME $_{\mathbf{n}}$ & TME & TME $_{\mathbf{n}}$ \\
\hline Temperature & & & & \\
Thermoneutral (N) & 2863 & 2863 & 3365 & 3364 \\
Heat stress (H) & 2855 & 2855 & 3358 & 3358 \\
Enzymes: & & & & \\
Without (W) & 2841 & 2841 & 3344 & 3343 \\
With optizyme (OP) & 2872 & 2872 & 3375 & 3375 \\
With phytase (PH) & 2864 & 2864 & 3365 & 3365 \\
Interactions: & & & & \\
N x W & 2837 & 2837 & 3339 & 3338 \\
N x OP & 2884 & 2884 & 3386 & 3386 \\
N x PH & 2869 & 2869 & 3369 & 3369 \\
H x W & 2845 & 2846 & 3348 & 3348 \\
H x OP & 2860 & 2861 & 3363 & 3363 \\
H x PH & 2858 & 2859 & 3361 & 3361 \\
& & Probability & & \\
Temperature (T) & NS & NS & NS & NS \\
Enzymes (E) & NS & NS & NS & NS \\
T x E & NS & NS & NS & NS \\
\hline
\end{tabular}

"Probability at 0.05 .

Table 5. The effect of heat stress and enzymes supplementation on apparent and true metabolizable energy values of rice bran

\begin{tabular}{lllll}
\hline Treatment & AME & AME $_{\mathbf{n}}$ & TME & TME $_{\mathbf{n}}$ \\
\hline Temperature & & & & \\
Thermoneutral (N) & 2611 & 2611 & 3363 & 3363 \\
Heat stress (H) & 2562 & 2563 & 3317 & 3317 \\
Enzymes: & & & & \\
Without (W) & 2470 & 2470 & 3224 & 3224 \\
With optizyme (OP) & 2707 & 2707 & 3461 & 3460 \\
With phytase (PH) & 2586 & 2586 & 3338 & 3337 \\
Interactions: & & & & \\
N x W & 2458 & 2458 & 3211 & 3211 \\
N x OP & 2705 & 2705 & 3458 & 3458 \\
N x PH & 2669 & 2570 & 3420 & 3420 \\
H x W & 2482 & 2483 & 3237 & 3237 \\
H x OP & 2709 & 2709 & 3460 & 3463 \\
H x PH & 2480 & 2480 & 3034 & 3034 \\
& & Probability & & \\
Temperature (T) & NS & NS & NS & NS \\
Enzymes (E) & NS & NS & NS & NS \\
T x E & NS & NS & NS & NS \\
\hline
\end{tabular}

${ }^{*}$ Probability at 0.05 . 
Table 6. The effect of heat stress and enzymes supplementation on apparent and true metabolizable energy values of wheat bran

\begin{tabular}{lcccc}
\hline Treatment & AME & AME $_{\mathbf{n}}$ & TME & TME $_{\mathbf{n}}$ \\
\hline Temperature & & & & \\
Thermoneutral (N) & 1662 & 1663 & 2417 & 2742 \\
Heat stress (H) & 1609 & 1610 & 2384 & 2384 \\
Enzymes: & & & & \\
Without (W) & 1585 & 1586 & 2372 & 2373 \\
With optizyme (OP) & 1664 & 1665 & 2418 & 2418 \\
With phytase (PH) & 1559 & 1659 & 2411 & 2411 \\
Interactions: & & & & \\
N x W & 1568 & 1569 & 2389 & 2389 \\
N x OP & 1653 & 1654 & 2406 & 2406 \\
N x PH & 1607 & 1608 & 2357 & 2357 \\
H x W & 1602 & 1602 & 2356 & 2356 \\
H x OP & 1675 & 1676 & 2430 & 2430 \\
H x PH & 1710 & 1711 & 2465 & 2465 \\
& & Probability & & \\
Temperature (T) & NS & NS & NS & NS \\
Enzymes (E) & NS & NS & NS & NS \\
T x E & NS & NS & NS & NS \\
\hline * Probability at 0.05. & & &
\end{tabular}

${ }^{*}$ Probability at 0.05 .

\subsection{Effect of enzyme supplementation on energy bioavailability}

The impact of enzymes supplementation on the different values of metabolizable energy tended to be positive in case of rice bran and wheat bran and the effect was more pronounced in case of optizyme supplementation than in case of phytase supplementation specially for rice bran (Tables 5, 6). However, the differences didn't reach a significant level. The improvements in the forms of metabolizable energy at optizyme supplementation in these two feedstuffs may be mainly related to some increase in nutrient digestibility (fat, starch) and due to the non-starch polysaccharide (NSP) become partially available to the birds as a substantial energy source (Broz, 1993 and Annison, 1995).

Also, similar trend for improvement was found with phytase supplementation in regard to the energy values of rice bran and wheat bran; however the improvement was less with mung bean and sorghum. The improvements of metabolizable energy values in the present study due to the effect of phytase may be due to a partial increase in hydrolyzing phytic acid, which in turn may enhance the digestion of protein, starch and fat. Many authors mentioned that phytase enhanced starch digestion (Farrell and Martin, 1998; Ravindran et al. 1999 and Ravindran et al. 2000).

\subsection{Effect of interaction between heat stress and enzymes supplementation on energy bioavailability}

The interaction between thermoneutral conditions and enzymes supplementation was not significant in case of mung beans and sorghum, however, there was an insignificant increase in case of wheat bran and rice bran, where it led to higher metabolizable energy values specially for optizyme supplementation with rice bran. 
The interaction between heat stress and enzyme supplementation (optizyme or phytase) was not significant, however, it led to numerical increase in metabolizable energy values of mung beans and wheat bran. Also, there was an insignificant increase in case of rice bran at optizyme supplementation. Therefore, it could be summarized that metabolizable energy values tended to be negatively affected by heat stress for mung beans, wheat bran and rice bran but not for sorghum. Also, enzyme supplementation specially optizyme tended to increase different forms of metabolizable energy values under both neutral and high temperatures in case of rice bran and wheat bran. Rice bran was more positively affected by enzymes supplementation.

\section{CONCLUSION}

It may be concluded that the effect of heat stress (at $38^{\circ} \mathrm{C}$ ) on different metabolizable energy values tended to be negative. This may raise the risk which could happened at higher temperatures in summer times where it is almost always higher than $38^{\circ} \mathrm{C}$ and some times exceeding $40^{\circ} \mathrm{C}$. The impact of enzymes supplementation on energy values was positive in general. However, it may be more effective at higher levels of supplementation than those used in this study (1500 FTU phytase or $0.3 \mathrm{~g}$ optizyme $/ \mathrm{kg}$ feed). It is hard to generalize a recommendation as regards enzymes supplementation to the different feedstuffs under thermoneutral or heat stress conditions. Optizyme and phytase seemed to be better for rice bran and wheat bran than for mung bean and sorghum, however, optizyme may be better for rice bran under heat stress while phytase may be better for wheat bran under similar conditions.

\section{REFERENCES}

Annison, G., 1995. Feed enzymes. The science, future developments and practical aspects in feed formulation. In: $10^{\text {th }}$ European Symposium on poultry nutrition. WPSA. October 15-19, Antalya, Turkey, pp 193-201.

Annison, G., P. J. Moughan, and D. V. Thomas, 1995.Nutritive activity of soluble rice bran arabinoxylans in broiler diets. Br. Poult. Sci., 36: 479-488.

Ashour,N.L, T.G. Behairy, E.M. Abd EL Lateef, and M.M Selim,1991. A preliminary study on potentiality of inter crossing of mung bean (Vigna radiate) with dwarf grain sorghum (Sorghumbicolar Moench) in Egypt. NRC.Egypt. 16 (1) 53-60. (in Arabic).

Association of Official Analytical Chemists A.O.A.C., 1984. Offical Methods of Analysis $13^{\text {th }}$ ED. Publised by the A.O.A.C., Benjamin Franklin Washington, D.C.

Attia F.A.,P. E Waibel; I. Hermes; C.W. Carlson, and M.M. Walsert 2000. Effect of dietary phosphours, calcium, and phytase on performance of growing turkeys. Poult. Sci., 79:231-239.

Bedford M. R., 1996. The effect of enzymes on digestion.J. of Appl. Poult. Res. 5: 370-378.

Boling, S.D.,M,W. Douglas,R.B. Shirley, C.M. Parsons and K.W. Koelkebeck. 2000. The effect of various dietray levels of phytase and available phosphours on performance of laying hens. Poult.Sci., 79:535-538. 
Bonnet,S., P. A. Geraert, M. Lessire, B. Carre, and Guillaumin Solange, 1997. Effect of high ambient temperature on Feed digestibility in broilers . Poult. Sci. 76:857863.

Broz, J., 1993. Enzymes as feed additives in poultry nutrition. Current applications and future trends. Monatshefte fur Venterinar-Medizine 48,213-217.

Broz, J., P. Oldale, A. H. Perrrin-Voltz, G. Rychen, J. Schulze, and C. Simoes, Nunes, 1994. Effects of supplemental phytase on performance and phosphorus utilization in broiler chickens fed a low phosphorus diet without addition of inorganic phosphates. Br. Poult. Sci. 35:273-280.

Chitra, U., V. Vimala, U.Singh, and P. Geervain, 1995. Phytic acid content and protein digestibility of grain legumes. Plant Food Human Nutrition, 47:163.

Choct, M., 2002. Non-starch polysaccarides: Effect on nutritive value. In:"Poultry Feedstuffs", Chapter 13. Ed. J.M. McNab and K.N. Boorman, CABI Publishing, Wallingford, UK.

Creswell, D., 1981. Nutritional evaluation of mung beans (phaseolus aureus) for young broiler chickens. Poult. Sci. 60:1905.

Duncan, D. B., 1955. The Multiple Range and Multiple F Test. Biometrics.11:1-42.

El-Alfy, M.A., 1998. A study on using of mung bean in broiler diets as a nontraditional feedstuffs. M. Sc. Thesis. Fac. of Agric., Al-Azhar University.

El-Husseiny, O. and C.R. Greger, 1980. The effect of ambient temperature on carcass energy gain in chickens. Poult. Sci., 59:2307-2311.

El-Sayed, A.A. R., 1999. Biochemical and technological studies on mung bean seeds. M. Sc. Thesis. Food Sci. and Technol. Dept. Fac. of Agric. Assiut Univ. Assiut, Egypt.

Farrell, D. J. and E.A. Martin, 1998. Strategies to improve the nutritive value of rice bran in poultry diets. 1. The addition of food enzymes to target the non-starch polysaccharide fractions in diets of chickens and ducks gave non response. Br. Poult. Sci., 39:549-554.

Fayek, H. M. and Y. A. Mady, 1989. Protein quality of Egyptian and imported sorghum grains as compared to yellow corn. Egypt. Poult. Sci., 9:115-131.

Fayek, H. M.,Y. A. Mady, and M.S. Shulkamy, 1989. Incorporation of Egyptian sorghum grains in broiler diets. Egypt. Poult. Sci., 9: 99-114.

Geraert, P.A., S. Guillaumin, and M. Zuprizal, 1992. Effect of ambient temperature on dietary metabolizable energy values in genetically lean and fat chickens. Poult. Sci., 71: 2113-2116.

Gualtieri, M. and S. Rapaccini, 1990. Sorghum grain in poultry feeding. World's Poult. Sci. J. Vol. 46 No. V: 246-254.

Hurwitz, S., M. Weiselberg, U. Eiset, I. Bartov, G. Riesenfeld, M. Sharvit, A. Niv, and S. Bornstein, 1980. The energy requirements and performance of growing chickens and turkeys as affected by environmental temperature. Poult. Sci., 59:2290-2299.

Ibrahim, M.S., C.Fisher, H.El-Alaily, H. Soliman and A. Anwar, 1988. Improvement of the nutritional quality of Egyptian and Sudanese sorghum grains by the addition of phosphates. Br. Poult. Sci., 29:721-728.

Jeroch, H., and W. Peter, 1994. The effectiveness of microbial phytase in layer diet based on maize and wheat. Institut fur Tiernahrung und Vorratshaltung, MartinLuther Universitat Halle-Wittenberg. 
Keshavarz, K., 2000. Nonphytate phosphorus requirement of laying hens with and without phytase on phase feeding program. Poult. Sci., 79: 748-763.

Keshavarz, K. and H.L. Fuller, 1980. The influence of widely fluctuating temperature on heat production and energetic efficiency of broiler. Poult. Sci., 59: 2121-2128.

Khalil, M. M., 1996. Enrichment of biscuts using isolated protein from mung bean seeds. Zagazig J. Agric. Res., 23 (4):517-531.

Khalaf Allah, M. A., 1995. Changes in chemical constituents of mung beans (phaseolu aurues) as affected by dehulling, soaking and germination. Egypt. J. Appl. Sci., 10 (1):56.

Kienholz, E.W., L.S. Jensen and J. McGinnis, 1962. Evidence for chick growth inhibitors in several legume seeds. Poult. Sci., 41:367-371.

Koelkebeck, K.W., C.M. Parsons and N. Xincheng 1998. Effect of acute heat stress on amino acid digestibility in laying hens. Poult. Sci. 77:1393-1396.

Luis, E. S., and T.W. Sullivan 1982. Nutrient composition and feeding values of pro millets sorghum grains and corn in broiler diets. Poult. Sci., 61: 311-320.

Makled, M. N., and O. Afifi, 2000. Sorghum plus methionine supplementation as a substitute for yellow corn in broiler diets. $21^{\text {st }}$ World's Poult. Congress, Montereal, Canada, 2000.

Makled, M. N., K.W. Koelkebeck, C.M. Parsons, and A.B. Corless, 2000. Effect of acute cyclic and constant heat stress on true metabolizable energy of four feedstuffs. World's Poult. Sci. Conf. Montereal, Canada, 2000.

Metwally, M.A. 1990. Evaluation of the metabolizable energy of some poultry feedstuffs. M. Sc. Thesis, Fac. of Agric., Assiut Univ.

Namkung, H., and S. Leeson, 1999. Effect of phytase enzyme on dietary nitrogen corrected apparent metabolizable energy and ileal digestibility of nitrogen and amino acid in broiler chicks. Poult. Sci., 78:1317-1319.

NRC, 1994. National Research Council, Nutrient Requirements of Poultry. $9^{\text {th }}$ Revised Edition. National Academy Press, Washington, DC. USA.

Nyachoti, C. M., J.L. Atkinson and S. Leeson 1997. Sorghum tannins: a review. World's Poult. Sci., 53: 5-21.

Qian, T., E.T. Kornegay and D.M. Denbow, 1996. Phosphorus equivalence of microbial phytase in turkey diets as influenced by calcium and phosphorus ratio and phosphorus levels. Poult. Sci., 75:69-81.

Ravindran, V., and W.L. Bryden, 1997. Influence of phytic acid and available phosphorus level on response of broilers to supplement Natuphos. Poult. Res. Foundation Rep., Univ. of Sidney, Australia.

Ravindran, V., S. Cabahug, G. Ranindran, W.L. Bryden, and P.H. Selle,1999. Influence of microbial phytase on apparent ileal amino acid digestibility of feedstuffs for broilers. Poult. Sci., 78:699-706.

Ravindran, V., S. Cabahug, G. Ranindran, W.L. Bryden, and P.H. Selle, 2000. Response of broilers to microbial phytase supplementation as influenced by dietary phytic acid and non-phytate phosphorus levels.II. Effects on nutrient digestibility and retention. Br. Poult. Sci. 41:193-200.

Rosario, R.R., and M.G. Noel, 1980. The chemical and biochemical composition of legume seeds (mung bean) philippino agriculture. 63:267-274.

SAS, 1987. SAS/STAT Guide for personal computer (Version 6), SAS Institute. Cary, NC. 
Savory, L.C., 1986. Influence of ambient temperature on feeding activity parameters and digestive function in domestic fowls. Physiol. Behav. 38:353-357.

Schoner, F. J., P.P. Hoppe, and G. Schwarz, 1991. Chicken feeding experiment with microbial phytase: Comparison of effectiveness with inorganic phosphate with varying Ca supply. Vitamine and Weitere Zusatzstoff bei Mensch und Tier. 3. Symposium, Jena.

Sibbald, I. R., 1976. A bioassay for true metabolizable energy in feedingstuffs. Poult. Sci., 55:303-308.

Sibbald, I. R., 1986. The TME system of feed evaluation: methodology, feed composition data and bibliography. Research Branch Contribution 85-1B, Technical Bulletin No. 1986-4E. Animal Research Center, Agriculture Canada, Ottawa, Canada, P. 114.

Simons, P. C.M., H.A. J. Versteegh, A.W. Jongbloed, P.A. Kemme, P. Slump, K.D. Bos, M.G.E. Wolters, R.F. Beudeker, and G.J. Vershoor, 1990. Improvement of phosphorus availability by microbial phytase in broiler and pigs. Br. J. Nutr. 64: 525-540.

Sullivan, T.W., 1987. Evaluation of sorghum varieties in poultry rations. Feed Facts, Grains Sorghum Producers Association. April, 15. Vol. 4 (4). Cited from Attia, Y.A. 1998. Nutritive value of the Egyptian sorghum grains (Giza 15) as a feedstuff in broiler diets. Egypt. Poult. Sci., 18: 311-336.

Van der Klis, J., H.A.J. Vesteegh, P.C. M. Simons and A.K. Kies, 1997. The efficacy of phytase in corn soybean meal based diets for laying hens. Poult. Sci., 76:15351542.

Wallis, I.R. and D. Balnave, 1984. The influence of environmental temperature, age and sex on the digestibility of amino acids in growing broiler chickens. Br. Poult. Sci., 25:401-407.

Wu,Y.B., V.Ravindean and W.H. Hendriks 2004. Effects of microbial phytase, produced by solid-state fermentation, on the performance and nutrient utilization of broilers fed maize-and wheat-based diets. British Poult. Sci. 44:710-718.

Zuprizal, M., A.M. Larbier, A.M. Chagneau and P.A. Geraert, 1993. Influence of ambient temperature on true digestibility of protein and amino acids of rapeseed and soybean meals in broilers. Poult. Sci., 72:289-295. 
تأثير الإجهاد الحراري وإضافة الأنزيمات على الطاقة الممثلة حيويا لبعض مواد العلف ألف المستخدمة فى أعلاف الدواجن

\author{
محمد نبيل مقلد ${ }^{1}$ طلعت مصطفى الثيخ ${ }^{2}$ ـ محد متولى احمد ـ سناء النجار2 \\ ا - قسم الإنتاج الحيواني والدواجن، كلية الزراعة، جامعة أسيوط، ؟- قسم الإنتاج الحيواني والدواجن، كلية

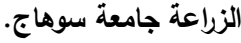 \\ أجريت أربع تجارب منثابهة استخدم فيها اربع مواد علف وهى فول المانج ، الذرة الرفيعة، رجيع الكون

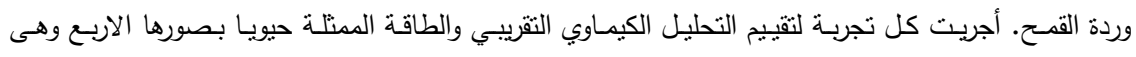

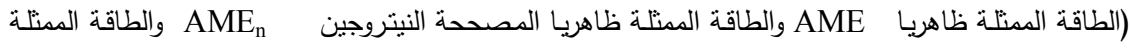

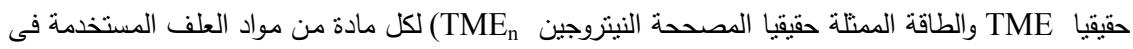

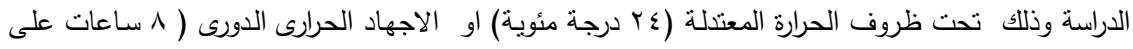

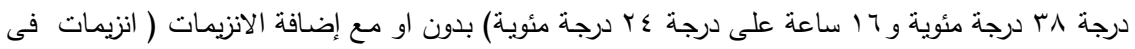

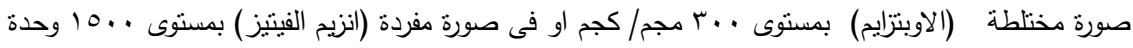

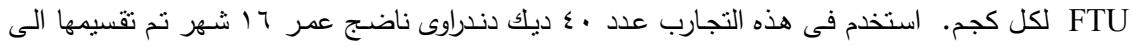 \\ ثمانية مجموعات كل منها خمس ديوك وتم تغذيت الديوك بتكنيك الدفع الغذائي لنقدير الطاقة المثنلة الظاهرية \\ والحقيقية واظهرت النتائج مايلى:

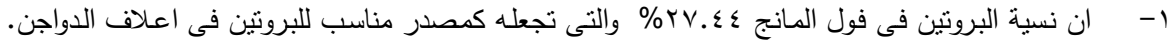

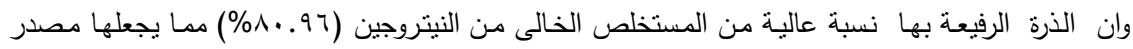

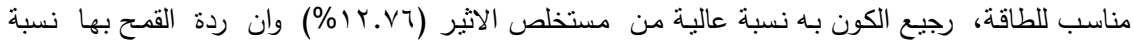

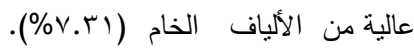 \\ r- ادى الإجهاد الحرارى الى انخفاض قيم AME, AME \\ الدراسة ماعدا الذرة الرفيعة حيث ان الانخفاض فيها لم يكن معنويا.

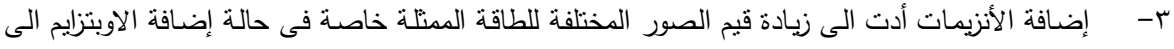

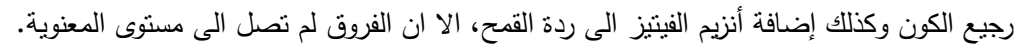

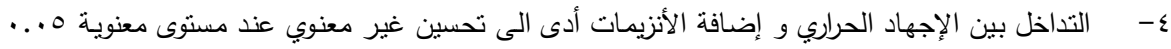

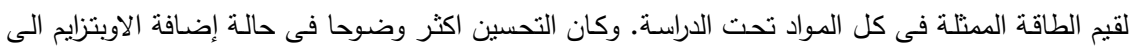 \\ رجيع الكون وكذلك إضافة الفيتيز الى ردة القمح تحت الإجهاد الحرارى.
}

